\title{
ANALISIS KOMPETENSI PROFESIONAL GURU PAUD KABUPATEN SIAK PROVINSI RIAU
}

\author{
Febrialismanto \\ Prodi PG PAUD FKIP Universitas Riau \\ email:febrialismanto@lecturer.unri.ac.id
}

\begin{abstract}
Abstrak: Analisis Kompetensi Profesional Guru PAUD Kabupaten Siak Provinsi Riau. Guru merupakan faktor penentu keberhasilan dari sebuah proses pendidikan. Guru harus memiliki kompetensi dalam mendidik salah satu kompetensi guru adalah kopetensi profesional. Kompetensi profesional menggambarkan kemampuan guru menguasai materi pembelajaran. Tujuan penelitian ini untuk menganalisis kemampuan kompetensi guru paud yang telah menyelesaikan studi S1 yang berada di kabupaten Siak. Metode yang digunakan adalah dekripsi kuantitatif dengan melakukan test terhadap 36 orang guru. Dari hasil penelitian dapat diketahui indikator yang termasuk dalam kategori rendah adalah Menguasai konsep dasar kesehatan dan gizi sebagai sarana pengembangan untuk setiap bidang pengembangan anak dengan nilai $44.44 \%$, memahami kemampuan anak TK/PAUD dalam setiap bidang pengembangan $43.52 \%$, dan memahami kemajuan anak dalam setiap bidang pengembangan di TK/PAUD 49.07\%. Dari hasil penelitian tersebut dapat diketahui bahwa tiga indikator tersebut tergolong kategori rendah dibandingkan dengan indikator-indikator kompetensi profesional yang lainnya.
\end{abstract}

Kata Kunci: Kompentensi Profesional, Guru Paud, Kabupaten Siak

Abstract:Analysis of Early Childhood Education Teacher Professional Competency In Siak Regency, Riau Province. Teachers are the critical success factors of an educational process. Teachers must have competence in educating one of the competencies of teachers is professional competence. Professional competence describes the ability of teachers to master learning materials. The purpose of this study is to analyze the competence of paud teachers who have completed the S1 study located in Siak regency. The method used is quantitative decryption by conducting tests on 36 teachers. From the results of the research can be seen that the indicators included in the low category is Mastering the basic concepts of health and nutrition as a means of development for each field of development of children with a value of $44.44 \%$, understand the ability of children kindergarten in every field of development $43.52 \%$, and understand the progress of children in every field development in kindergarten $49.07 \%$. From the results of this study can be seen that the three indicators are categorized as low compared with other indicators of professional competence.

Keyword: Professional Competence, Early Childhood Education Teacher, Siak Regency 
Dalam dunia pendidikan keberadaan guru merupakan hal yang sangat penting. Guru merupakan ujung tombak terlaksananya pendidikan. Salah satu permasalahan dalam pendidikan nasional khususnya pada tingkatan paud adalah kekurangan guru, penyebaran guru yang tidak merata dan tingkat pendidikan guru yang belum S1. Untuk meningkatkan kualifikasi guru paud pemerintah mengeluarkan keputusan Menteri Pendidikan Nomor: 015/P/2009 tentang penetapan perguruan tinggi penyelenggara program sarjana (S1) kependidikan bagi guru dalam jabatan. Pendidik yang sudah mengajar tetapi belum memiliki kualifikasi pendidikan $\mathrm{S} 1$ diberikan kesempatan untuk melanjutkan studinya. Dengan harapan setelah menempuh pendidikan pendidik dapat memiliki kompetensi sebagai seorang guru. Kunandar (2007:40) ditangan gurulah akan dihasilkan peserta didik yang berkualitas, baik secara akademis, skill (keahlian), kematangan emosional, moral, dan spiritual. Oleh karena itu diperlukan sosok guru yang mempunyai kualifikasi kompetensi, dan dedikasi dalam melaksanakan tugas profesionalnya.

Memiliki kompetensi merupakan syarat mutlak yang harus dimiliki oleh seorang guru dalam melaksanakan pendidikan. Guru sebagai ujung tombak pendidikan menentukan hasil pembelajaran yang akan dihasilkan. Proses pendidikan yang diikuti peserta didik berjalan sesuai dengan kemampuan atau kompetensi yang dimiliki oleh guru tersebut. Dilihat dari pengertian kompetensi menurut Lefrancois dalam Harina Yuhetty dkk, (2009:2) merupakan kapasitas untuk melakukan sesuatu, yang dihasilkan dari proses belajar. Selama proses belajar stimulus akan bergabung dengan isi memori dan menyebabkan terjadinya perubahan kapasitas untuk melakukan sesuatu. Apabila individu sukses mempelajari cara melakukan satu pekerjaaan yang kompleks dari sebelumnya, maka pada diri individu tersebut pasti sudah terjadi perubahan kompetensi. Perubahan kompetensi tidak akan tampak apabila selanjutnya tidak ada kepentingan atau kesempatan untuk melakukannya. Dengan demikian bisa diartikan bahwa kompetensi adalah berlangsung lama yang menyebabkan individu mampu melakukan kinerja tertentu.

Kompetensi diartikan oleh Cowell dalam Harina Yuhetty dkk, (2009:3) sebagai suatu keterampilan/kemahiran yang bersifat aktif. Kompetensi dikategorikan mulai dari tingkat sederhana atau dasar hingga lebih sulit atau kompleks yang pada gilirannya akan berhubungan dengan proses penyusunan bahan atau pengalaman belajar, yang lazimnya terdiri dari: (1) penguasan minimal kompetensi dasar, (2) praktik kompetensi dasar, dan (3) penambahan penyempurnaan atau pengembangan terhadap kompetensi atau keterampilan. Ketiga proses tersebut dapat terus berlanjut selama masih ada kesempatan untuk melakukan penyempurnaan atau pengembangan kompetensinya. Berdasarkan uraian di atas, maka dapat disimpulkan bahwa kompetensi merupakan satu kesatuan yang utuh yang menggambarkan potensi, pengetahuan, keterampilan, dan sikap yang dinilai, yang terkait dengan profesi tertentu berkenaan dengan bagian-bagian yang dapat diaktualisasikan dan diujudkan dalam bentuk tindakan atau kinerja untuk menjalankan profesi tertentu.

Kompetensi menurut Usman di dalam Kunandar (2007:51) adalah suatu hal yang menggambarkan kualifikasi atau kemampuan seseorang, baik yang kualitatif maupun kuantitatif. Pengertian ini mengandung makna bahwa kompetensi itu dapat digunakan dalam dua konteks, yakni: pertama, sebagai indikator kemampuan yang menunjukkan kepada perbuatan yang diamati. Kedua, sebagai konsep yang mencakup aspekaspek kognitif, afektif, dan perbuatan serta tahap-tahap pelaksanaannya secara utuh.

Sedangkan Abdul Majid (2008:5) menjelaskan bahwa kompetensi adalah seperangkat tindakan intelegen penuh tanggung jawab yang harus dimiliki seseorang 
sebagai syarat untuk dianggap mampu melaksanakan tugas-tugas dalam bidang pekerjaan tertentu. Sifat intelgen harus ditunjukkan sebagai kemahiran, ketepatan dan keberhasilan bertindak. Sifat tanggung jawab harus ditunjukkan sebagai kebenaran tindakan baik dipandang dari sudut ilmu pengetahuan, teknologi maupun etika. Dalam arti tindakan itu benar ditinjau dari sudut ilmu pengetahuan, efisien, efektif, dan memiliki daya tarik dilihat dari sudut teknologi dan baik ditinjau dari sudut etika. Dari pengertian tersebut dapat diketahui bahwa seorang guru yang memiliki kompensi dapat diketahui dari kemampuan itelegen yang dibuktikan dengan kemahiran dalam melakukan pekerjaan yang berhubungan dengan kemampuan guru yang haruskan dimilikinya yang tugas tersebut dilakukan penuh tanggung jawab dengan tetap menggunakan etika. Kemampuan tersebut karena adanya stimulus dan perubahan dalam memori pada diri seseorang guru. Kompetensi guru akan dapat dilihat apabila ada kesempatan untuk menunjukannya.

Salah satu kompetensi yang harus dimiliki oleh guru adalah kompetensi prosesional. Menurut Christian Dicky (2008:34) istilah profesional mengacu pada dua hal. Pertama orang yang menyandang suati profesi. Kedua, kinerja atau performance seseorang dalam melakukan pekerjaan yang sesuai dengan profesinya. Orang yang profesional biasanya melakukan pekerjaannya secara otonom dan mengadikan dirinya pada kepuasan pengguna jasa dengan disertai rasa tanggung jawab atas kemampuan profesionalnya itu. Wina Sanjaya (2009:4) menjelaskan bahwa Undang-Undang No 14 Tahun 2005 tentang Guru dan Dosen, Bab I Pasal 1 bahwa guru adalah pendidik profesional dengan tugas utama mendidik, mengajar membimbing, mengarahkan, melatih, menilai, dan mengevaluasi peserta didik pada pendidikan anak usia dini jalur pendidikan formal, pendidikan dasar, dan pendidikan menengah.
Berdasarkan

undang-undang

tersebut, ada dua hal yang perlu garis bawahi, pertama, Guru adalah jabatan profesional, yakni jabatan yang hanya dapat dilakukan oleh orang-orang yang memiliki latar belakang akademik keguruan. Dengan demikian, tidak setiap orang dapat menjadi guru profesional. Kedua, tugas guru yang profesional itu adalah mendidik, mengajar, membimbing, mengarahkan, melatih, menilai, dan mengevaluasi. Dengan demikian, melalui tugas yang begitu berat itu, keberhasilan pembentukan peserta didik atau pembentukan generasi manusia ada di pundak guru.

Dalam Peraturan Menteri Pendidikan Nasional Republik Indonesia nomor 16 Tahun 2007 standar kompetensi guru PAUD/TK/RA menyebutkan tentang kompetensi profesional sebagai berikut yakni: (1) Menguasai materi, struktur, konsep dan pola pikir keilmuan yang mendukung mata pelajaran yang diampu, (2) Menguasai standar kompetensi dan kompetensi dasar mata pelajaran/bidang pengembangan yang diampu, (3) Mengembangakan materi pembelajaran yang diampu secara kreatif, Mengembangakan keprfesionalan secara berkelanjutan dengan melakukan tindakan reflektif, dan (5) Memanfaatkan teknologi informasi dan komunikasi untuk berkomunikasi dan mengembangkan diri.

Dari hasil penelitian febrialismanto (2015) Secara umum kompetensi profesional berada pada kategori cukup tinggi dalam membentuk kinerja mengajar guru dengan nilai 75.88\% di kecamatan kampar kabupaten kampar.

\section{METODE}

Yang digunakan dalam penelitian ini adalah metode penelitian deskriptif kuantitatif. Metode desktiptif kuantitatif melihat bagaimana kondisi variable penelitian dengan melihat indikator-indikator yang menerangkan 
variabel tersebut. Populasi penelitian alumni Program Sarjana Kependidikan Guru dalam Jabatan (PSKGJ) FKIP Universitas Riau yang berasal dari Kabupaten Siak berjumlah 36 orang yang kemudian dijadikan sampel semua. Data penelitian dikumpulkan dengan cara melakukan test yang ditabulasikan ke dalam tabel dan dilihat persentase yang kemudian dinarasikan kondisi yang ditemukan sehingga dapat diketahui kondisi kompetensi profesional guru yang akan ditafsirkan dan disimpulkan temuan penelitian tersebut.

Pada penelitian ini dari lima aspek kompetensi profesional aspek pertama Menguasai materi, struktur, konsep dan pola pikir keilmuan yang mendukung mata pelajaran yang diampu dikembangkan menjadi 3 (tiga) aspek.

\section{HASIL DAN PEMBAHASAN}

Kriteria peneilaian menggunakan pedoman yang dikemukakan oleh Purwanti dalam Tuti Hayati dalam febrialismanto (2010) sebagai berikut:
a. $\quad>80 \%$ : Kondusif/Tinggi
b. $>60 \%-<80 \%$ :
Kondusif/Cukup Tinggi
c. $>40 \%-<60 \%$ :Kurang
Kondusif/Rendah
d. $<40 \%$ : Tidak Kondusif/Sangat Rendah

Dalam tabel dibawah ini akan lebih banyak menunjukkan data mengenai penguasaan materi, struktur, konsep dan pola pikir keilmuan yang mendukung mata pelajaran yang diampu berdasarkan aspekaspek yang diteliti dalam penelitan.
Tabel 1

Konsep Dasar Matematika, Sains, Bahasa, Pengetahuan Sosial, Agama, Seni,

Pendidikan Jasmani, Kesehatan Dan Gizi Sebagai Sarana Pengembangan Untuk Setiap Bidang Pengembangan Anak TK/PAUD

\begin{tabular}{|c|c|c|c|c|c|}
\hline $\begin{array}{l}\mathbf{N} \\
\mathbf{0}\end{array}$ & Indikator & $\begin{array}{l}\text { Skor } \\
\text { Ideal }\end{array}$ & $\begin{array}{c}\text { Skor } \\
\text { Aktual }\end{array}$ & $\%$ & $\begin{array}{c}\text { Kriteri } \\
\mathbf{a}\end{array}$ \\
\hline 1 & $\begin{array}{l}\text { Menguasai } \\
\text { konsep dasar } \\
\text { matematika } \\
\text { sebagai sarana } \\
\text { pengembangan } \\
\text { untuk setiap } \\
\text { bidang } \\
\text { pengembangan } \\
\text { anak }\end{array}$ & 108 & 97 & $\begin{array}{c}89.8 \\
1\end{array}$ & Tinggi \\
\hline 2 & $\begin{array}{l}\text { Menguasai } \\
\text { konsep dasar } \\
\text { sains sebagai } \\
\text { sarana } \\
\text { pengembangan } \\
\text { untuk setiap } \\
\text { bidang } \\
\text { pengembangan } \\
\text { anak }\end{array}$ & 108 & 87 & $\begin{array}{c}80.5 \\
6\end{array}$ & Tinggi \\
\hline 3 & $\begin{array}{l}\text { Menguasai } \\
\text { konsep dasar } \\
\text { bahasa sebagai } \\
\text { sarana } \\
\text { pengembangan } \\
\text { untuk setiap } \\
\text { bidang } \\
\text { pengembangan } \\
\text { anak }\end{array}$ & 108 & 67 & $\begin{array}{c}62.0 \\
4\end{array}$ & $\begin{array}{l}\text { Cukup } \\
\text { Tinggi }\end{array}$ \\
\hline 4 & $\begin{array}{l}\text { Menguasai } \\
\text { konsep dasar } \\
\text { pengetahuan } \\
\text { sosial sebagai } \\
\text { sarana } \\
\text { pengembangan } \\
\text { untuk setiap } \\
\text { bidang } \\
\text { pengembangan } \\
\text { anak }\end{array}$ & 108 & 77 & $\begin{array}{c}71.3 \\
0\end{array}$ & $\begin{array}{l}\text { Cukup } \\
\text { Tinggi }\end{array}$ \\
\hline 5 & $\begin{array}{l}\text { Menguasai } \\
\text { konsep dasar } \\
\text { agama sebagai } \\
\text { sarana } \\
\text { pengembangan } \\
\text { untuk setiap } \\
\text { bidang } \\
\text { pengembangan } \\
\text { anak }\end{array}$ & 108 & 66 & $\begin{array}{c}61.1 \\
1\end{array}$ & $\begin{array}{l}\text { Cukup } \\
\text { Tinggi }\end{array}$ \\
\hline 6 & $\begin{array}{l}\text { Menguasai } \\
\text { konsep dasar } \\
\text { seni sebagai } \\
\text { sarana } \\
\text { pengembangan } \\
\text { untuk setiap } \\
\text { bidang } \\
\text { pengembangan } \\
\text { anak }\end{array}$ & 108 & 99 & $\begin{array}{c}91.6 \\
7\end{array}$ & Tinggi \\
\hline
\end{tabular}




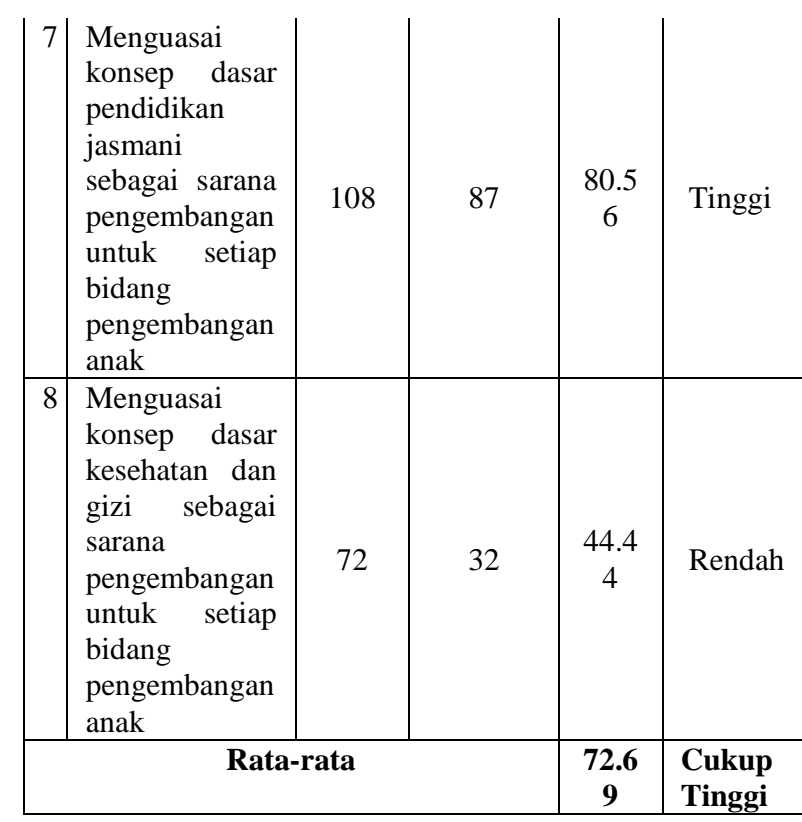

Tabel 2

Penggunaan Berbagai Alat Permainan

Untuk Mengembangkan Aspek Fisik,

Kognitif, Sosial Emosional, Nilai Moral, Sosial Budaya, Dan Bahasa

Anak TK/PAUD

\begin{tabular}{|c|c|c|c|c|c|}
\hline $\begin{array}{l}\mathbf{N} \\
\mathbf{0}\end{array}$ & Indikator & $\begin{array}{l}\text { Skor } \\
\text { Ideal }\end{array}$ & $\begin{array}{c}\text { Skor } \\
\text { Aktual } \\
\end{array}$ & $\%$ & Kriteria \\
\hline 1 & $\begin{array}{l}\text { Menguasai } \\
\text { alat } \\
\text { permainan } \\
\text { untuk } \\
\text { pengembanga } \\
\mathrm{n} \text { aspek fisik } \\
\text { anak } \\
\text { TK/PAUD }\end{array}$ & 72 & 59 & $\begin{array}{c}81.9 \\
4\end{array}$ & Tinggi \\
\hline 2 & $\begin{array}{l}\text { Menguasai } \\
\text { alat } \\
\text { permainan } \\
\text { untuk } \\
\text { pengembanga } \\
\text { n aspek } \\
\text { kognitif anak } \\
\text { TK/PAUD }\end{array}$ & 72 & 46 & $\begin{array}{c}63.8 \\
9\end{array}$ & $\begin{array}{l}\text { Cukup } \\
\text { Tinggi }\end{array}$ \\
\hline 3 & $\begin{array}{l}\text { Menguasai } \\
\text { alat } \\
\text { permainan } \\
\text { untuk } \\
\text { pengembanga } \\
\text { n aspek sosial } \\
\text { emosional } \\
\text { anak } \\
\text { TK/PAUD }\end{array}$ & 72 & 49 & $\begin{array}{c}68.0 \\
6\end{array}$ & $\begin{array}{l}\text { Cukup } \\
\text { Tinggi }\end{array}$ \\
\hline 4 & $\begin{array}{l}\text { Menguasai } \\
\text { alat } \\
\text { permainan } \\
\text { untuk } \\
\text { pengembanga } \\
\text { n aspek Nilai } \\
\text { moral anak }\end{array}$ & 72 & 53 & $\begin{array}{c}73.6 \\
1\end{array}$ & $\begin{array}{l}\text { Cukup } \\
\text { Tinggi }\end{array}$ \\
\hline
\end{tabular}

\begin{tabular}{|c|l|l|l|l|l|} 
& TK/PAUD & & & \\
\hline 5 & $\begin{array}{l}\text { Menguasai } \\
\text { alat } \\
\text { permainan } \\
\text { untuk } \\
\text { pengembanga } \\
\text { n aspek sosial } \\
\text { budaya anak } \\
\text { TK/PAUD }\end{array}$ & 72 & 65 & 90.2 & Tinggi \\
\hline 6 & $\begin{array}{l}\text { Menguasai } \\
\text { alat } \\
\text { permainan } \\
\text { untuk } \\
\text { pengembanga } \\
n \\
\text { bahasa anak } \\
\text { TK/PAUD }\end{array}$ & 72 & 66 & 91.6 & Tinggi \\
\hline
\end{tabular}

Tabel 3

Menguasai Berbagai Permainan Anak

\begin{tabular}{|c|l|c|c|c|c|}
\hline $\begin{array}{c}\text { N } \\
\text { o }\end{array}$ & Indikator & $\begin{array}{c}\text { Skor } \\
\text { Ideal }\end{array}$ & $\begin{array}{c}\text { Skor } \\
\text { Aktu } \\
\text { al }\end{array}$ & $\%$ & Kriteria \\
\hline 1 & $\begin{array}{l}\text { Menguasai } \\
\text { berbagai } \\
\text { permainan } \\
\text { anak }\end{array}$ & 72 & 63 & 87.5 & Tinggi \\
\hline \multicolumn{4}{|c|}{ Rata-rata } & $\mathbf{8 7 . 5}$ & Tinggi \\
\hline
\end{tabular}

Tabel 4

Memahami Kemampuan, Kemajuan, Tujuan Kegiatan Anak

\begin{tabular}{|c|c|c|c|c|c|}
\hline $\begin{array}{l}\mathbf{N} \\
\mathbf{0}\end{array}$ & Indikator & $\begin{array}{l}\text { Skor } \\
\text { Ideal }\end{array}$ & $\begin{array}{l}\text { Skor } \\
\text { Aktu } \\
\text { al }\end{array}$ & $\begin{array}{l}\text { Perse } \\
\text { ntase }\end{array}$ & Kriteria \\
\hline 1 & $\begin{array}{l}\text { Memahami } \\
\text { kemampuan } \\
\text { anak } \\
\text { TK/PAUD } \\
\text { dalam setiap } \\
\text { bidang } \\
\text { pengembang } \\
\text { an }\end{array}$ & 108 & 47 & 43.52 & Rendah \\
\hline 2 & $\begin{array}{l}\text { Memahami } \\
\text { kemajuan } \\
\text { anak dalam } \\
\text { setiap bidang } \\
\text { pengembang } \\
\text { an di } \\
\text { TK/PAUD }\end{array}$ & 108 & 53 & 49.07 & Rendah \\
\hline 3 & $\begin{array}{l}\text { Memahami } \\
\text { tujuan setiap } \\
\text { kegiatan } \\
\text { pengembang } \\
\text { an }\end{array}$ & 72 & 66 & 91.67 & Tinggi \\
\hline \multicolumn{4}{|c|}{ Rata-rata } & 61.42 & $\begin{array}{l}\text { Cukup } \\
\text { Tinggi }\end{array}$ \\
\hline
\end{tabular}


Tabel 5

Mengembangakan Materi Pembelajaran Yang Diampu Secara Kreatif

\begin{tabular}{|c|c|c|c|c|c|}
\hline $\begin{array}{c}\text { N } \\
\mathbf{0}\end{array}$ & Indikator & $\begin{array}{c}\text { Skor } \\
\text { Ideal }\end{array}$ & $\begin{array}{c}\text { Skor } \\
\text { Aktu } \\
\text { al }\end{array}$ & $\begin{array}{c}\text { Perse } \\
\text { ntase }\end{array}$ & Kriteria \\
\hline 1 & $\begin{array}{l}\text { Memilih } \\
\text { materi bidang } \\
\text { pengembanga } \\
\text { n yang sesuai } \\
\text { dengan } \\
\text { tingkat } \\
\text { perkembanga } \\
\text { n anak }\end{array}$ & 108 & 81 & 75.00 & $\begin{array}{l}\text { Cukup } \\
\text { Tinggi }\end{array}$ \\
\hline 2 & $\begin{array}{l}\text { Mengolah } \\
\text { materi bidang } \\
\text { pengembanga } \\
\text { n secara } \\
\text { kreatif sesuai } \\
\text { dengan } \\
\text { tingkat } \\
\text { perkembanga } \\
\text { n peserta } \\
\text { didik }\end{array}$ & 72 & 48 & 66.67 & $\begin{array}{l}\text { Cukup } \\
\text { Tinggi }\end{array}$ \\
\hline \multicolumn{2}{|l|}{ Rata-rata } & $\mathbf{7 0 . 8 3}$ & $\begin{array}{l}\text { Cukup } \\
\text { Tinggi }\end{array}$ \\
\hline
\end{tabular}

Tabel 6

Mengembangakan Keprofesionalan Secara

Berkelanjutan Dengan Melakukan Tindakan Reflektif

\begin{tabular}{|c|l|c|c|c|c|}
\hline $\begin{array}{c}\text { N } \\
\text { o }\end{array}$ & \multicolumn{1}{|c|}{ Indikator } & $\begin{array}{c}\text { Skor } \\
\text { Ideal }\end{array}$ & $\begin{array}{c}\text { Skor } \\
\text { Aktu } \\
\text { al }\end{array}$ & \% & Kriteria \\
\hline 1 & $\begin{array}{l}\text { Melakukan } \\
\text { refleksi } \\
\text { terhadap } \\
\text { kinerja sendiri } \\
\text { secara terus } \\
\text { menerus }\end{array}$ & 72 & 59 & 81.94 & Tinggi \\
\hline 2 & $\begin{array}{l}\text { Memanfaatka } \\
\text { n hasil } \\
\text { refleksi dalam } \\
\text { angka } \\
\text { peningkatan } \\
\text { keprofesional } \\
\text { an }\end{array}$ & 72 & 52 & 72.22 & $\begin{array}{l}\text { Cukup } \\
\text { Tinggi }\end{array}$ \\
\hline 3 & $\begin{array}{l}\text { Melakukan } \\
\text { penelitian } \\
\text { tindakan kelas } \\
\text { untuk } \\
\text { peningkatan } \\
\text { keprofesional } \\
\text { an }\end{array}$ & 72 & 56 & 77.78 & $\begin{array}{l}\text { Cukup } \\
\text { Tinggi }\end{array}$ \\
\hline 4 & $\begin{array}{l}\text { Mengikuti } \\
\text { kemajuan } \\
\text { zaman dengan } \\
\text { belajar dari } \\
\text { berbagai } \\
\text { sumber }\end{array}$ & 72 & 60 & 83.33 & Tinggi \\
\hline \multicolumn{2}{|c|}{ Rata-rata } & $\mathbf{7 8 . 8 2}$ & $\begin{array}{l}\text { Cukup } \\
\text { Tinggi }\end{array}$ \\
\hline
\end{tabular}

Tabel 7

Memanfaatkan Teknologi Informasi Dan Komunikasi Untuk Berkomunikasi Dan Mengembangkan Diri

\begin{tabular}{|c|l|c|c|c|c|}
\hline $\begin{array}{l}\text { N } \\
\text { o }\end{array}$ & Indikator & $\begin{array}{l}\text { Skor } \\
\text { Ideal }\end{array}$ & $\begin{array}{l}\text { Skor } \\
\text { Aktu } \\
\text { al }\end{array}$ & \% & Kriteria \\
\hline 1 & $\begin{array}{l}\text { Memanfaatka } \\
\text { n teknologi } \\
\text { informasi dan } \\
\text { komunikasi } \\
\text { dalam } \\
\text { berkomunikas } \\
\text { i }\end{array}$ & 36 & 28 & 77.78 & $\begin{array}{l}\text { Cukup } \\
\text { Tinggi }\end{array}$ \\
\hline 2 & $\begin{array}{l}\text { Memanfaatka } \\
\text { n teknologi } \\
\text { informasi dan } \\
\text { komunikasi } \\
\text { untuk } \\
\text { pengembanga } \\
\text { n diri }\end{array}$ & 36 & 33 & 91.67 & Tinggi \\
\hline \multicolumn{3}{|c|}{ Rata-rata } & $\mathbf{8 4 . 7 2}$ & Tinggi \\
\hline
\end{tabular}

\section{Pembahasan}

Dari 5 (lima) aspek kompetensi yang diteliti dapat diketahui ada 3 (tiga) indikator termasuk dalam kriteria rendah:

1. Menguasai konsep dasar kesehatan dan gizi sebagai sarana pengembangan untuk setiap bidang pengembangan anak nilai $44.44 \%$ kategori rendah.

Kemampuan menguasai kosep dasar kesehatan dan gizi merupakan salah satu kemampuan yang harus dimiliki oleh seorang guru. Dengan memiliki kemampuan pengetahuan tentang konsep dasar kesehatan dan gizi diharapkan guru dapat mempraktikkan di sekolah maupun memberikan informasi kepada orang tua anak. Dalam garis besar fungsi gizi dibagi dalam 3 kelompok besar, menurut Asmuni dalam Endang Rini Sukamti (1994) kelompok tersebut adalah: 1. Zat gizi sumber energi (tenaga): Hidrat Arang, Lemak, dan Protein. 2. Zat gizi pembangun tubuh: Protein. 3. Zat gizi pengatur: vitamin dan mineral. Zat-zat gizi di atas dalam jumlah yang adekwat dibutuhkan oleh tubuh dan harus didapatkan daJam 
makanan sehari-hari agar tubLih dapat menjalankan fungsinya dengan normal berupa: - pemeliharaan (maintenance), pertumbuhan, - perbaikan bagian tubuh yang rusak, aus. atau hilang, reproduksi, - kerja fisik, - Specific Dynamic Action (S.D.A)

Rita Kurnaia (2015) menjelaskan tentang Permasalahan Gizi

a. Peranan gizi berkhasiat bagi anakanak sejak kecil mampu meningkatkan pertumbuhan fisik serta memperbaiki keupayaan mental mereka.

b. Gizi seimbang mencakupi adalah karbohidrat, protein, vitamin, garam, dan mineral. Secara konsisten dapat mencegah serangan penyakit kronik seperti jantung dan kencing manis.

c. Bagaimanakah sikap orang tua dan masyarakat umumnya terhadap masalah seperti terhambatnya tumbuh kembang anak-anak dan penyakit kekurangan zat makanan.

d. Dapat dilihat $15 \%$ anak-anak luar kota mengidap penyakit kekurangan zat besi dan $20 \%$ lagi mengalami masalah terhambatnya tumbuh kembang.

e. Dalam tumbuh kembang anak nutrisi mempunyai dua peranan penting fisik dan kematangan seksual, serta memenuhi keperluan energi yang diperlukan anak. "dalam konteks kembang, menyiapkan otak sebagai hardware dalam proses pencerdasan".

f. Makanan ringan menyiapkan makanan kecil setelah beraktifitas di sekolah atau di rumah, seperti makanan haruslah bergizi, ada sayursayuran, buah-buahan, roti, protein, dan makanan yang mengandung gula tinggi haruslah dihindarkan.

Dari penjelasan tersebut dapat diketahui permasalahan gizi dapat terjadi pada anak dan memberikan dampak yang sangat signifikan bagi pertumbuhan dan perkembangan anak. Gizi yang didapat oleh anak bersumber dari makanan yang dimakannya. Makanan dapat dikelompokkan dalam zat dan fungsinya. Terdapat lima kelompok utama makanan yang disusun menurut aras tertentu dalam Piramid Makanan (Kemenkes dalam Rita Kurnia, 2015)

a. Biji dan makanan umbi-umbian terletak pada aras paling bawah di piramid makanan. Makanan kelompok ini kaya dengan sumber karbohidrat yang merupakan sumber tenaga yang penting. Selain itu, kelompok makanan ini mengandung vitamin, mineral, serat dan sedikit protein. Contoh makanan kelompok ini adalah nasi, mi, roti, pasta, bijibijian, bubur, capati, tosai, biskuit dan berbagai jenis ubi. Makanan kelompok ini perlu dimakan lebih banyak, yaitu $8-12$ sajian sehari.

b. Sayur-sayuran dan buah-buahan terletak pada aras kedua piramid. Kelompok ini mengandung vitamin, mineral dan serat yang dapat mencegah dan memulihkan berbagai penyakit. Sebagai pengamalan gizi yang sehat, sayur dan buah perlu dimakan sekurang-kurangnya lima sajian setiap hari dan digalakkan makan berbagai jenis sayur dan buah.

c. Daging termasuk ayam dan kacangan terletak pada aras ketiga di piramid. Kacangan soya dan hasilnya, kacang merah dan kacang hijau dapat menggantikan daging dan mengandungi rendah lemak. 
Makanan kelompok ini adalah sumber protein, vitamin dan berbagai zat seperti besi, zink, kalsium dan magnesium. Protein penting bagi tumbuh besar dan vitamin serta zat baik bagi mencegah berbagai penyakit. Makanan kelompok ini perlu dimakan sederhana saja.

d. Susu seperti keju dan dadih terletak sama aras dengan daging. Makanan kelompok ini adalah sumber kalsium yang penting dan perlu dimakan 1 2 sajian sehari.

e. Lemak dan gula serta makanan yang banyak mengandung bahan ini terletak pada aras paling atas dalam piramid. Makanan kelompok ini perlu dimakan sedikit saja dan berhati-hati.

2. Memahami kemampuan anak TK/PAUD dalam setiap bidang pengembangan nilai 43.52 kriteria rendah.

Kemampuan memahami kemampuan anak dalam setiap bidang pengembangan harus dimiliki oleh seorang guru. Ria Novianti \& Febrialismanto (2015) Kegiatan bermain bagi anak memiliki arti yang sangat besar dalam mengembangkan segenap aspek perkembangan yang ada padanya. Adapun manfaat bermain ketika dilakukan pada anak adalah:

a. Perkembangan aspek fisik: anak berkesempatan melakukan kegiatan yang melibatkan gerakan-gerakan tubuh yang membuat tubuh anak menjadi sehat dan otot-otot tubuh menjadi kuat.

b. Perkembangan motorik halus dan kasar: gerakan dan koordinasi tubuh.

c. Perkembangan emosi dan kepribadian: melepaskan ketegangan dalam tubuhnya, menyalurkan perasaan dan menyalurkan dorongan yang membuat anak relaks.

d. Perkembangan aspek kognitif: melalui bermain anak akan belajar melalui dan mengembangkan daya pikirnya.

e. Perkembangan alat indera: aspek penginderaan (penglihatan, pendengaran, penciuman, pengecapan, perabaan) perlu diasah agar anak lebih tanggap atau peka terhadap hal-hal yang ada disekitarnya.

f. Dapat mengembangkan keterampilan olahraga dan menari.

g. Media intervensi: melatih konsenterasi, seperti melatih konsep dasar warna, bentuk, dll.

h. Sebagai media terapi (anak merasa puas karena mereka dapat tampil bebas).

Dari aspek fisik guru harus mengetahui bagaimana aspek fisik tersebut dapat berkembang dengan optimal, cara yang dilakukan dapat dengan menyediakan fasislitas-fasilitas bermain anak baik di dalam ruangan maupun di luar ruangan. Fasilitas tersebut seperti tersedianya bola dari berbagai ukuran yang bisa digunakan oleh anak, alat permainan seperti ayunan, terowongan, alat fasislitas memanjat, fasilitas untuk berlari, dan fasilitas melompat. Selain menyediakan fasilitas tersebut guru harus mengetahui bagaimana cara menggunakan fasilitas tersebut untuk anak.

Untuk mengembangakan aspek motorik guru harus memberikan fasilitas yang berbeda untuk motorik kasar dan motorik halus. Secara umum untuk motorik kasar tidak berbeda dengan 
fasilitas yang disediakan untuk kemampuan fisik tetapi untuk motorik halus guru harus memberikan fasilitas yang berbeda seperti alat-alat untuk menjahit, meronce, dan mengayam. Selain itu guru juga harus mampu mengembangakan kegiatan yang berhubungan dengan motorik halus dengan menguasai semua kegiatan yang berhubungan dengan motorik halus.

Menguasai pengembangan emosi dan kepribadian merupakan suatu kewajiban bagi guru anak usia dini. Pada usia dini anak mulai belajar mengembangakan kemampuan emosi dan kepribadian mereka. Untuk meningkan kemampuan tesebut guru harus memfasilitasi dengan kegiatankegiatan yang dapat mengembangkan kemampuan emosi dan kepribadian tesebut. Bentuk dari pengembangan kemampuan tesebut bisa seperti kegiatan bermain bersama, kegiatan bermain peran, dan kegiatan lainnya. Kemapuan emosi dan kepribadian yang baik pada anak akan membantu mereka dalam bersosialisasi pada lingkungan mereka. Anak yang memiliki kekampuan emosi dan kepribadian yang baik akan lebih mudah diterima dalam lingkungan sebaiknya anak yang tidak memiliki kemampuan emosi dan kepribadian yang baik akan lebih sulit untuk masuk dalam lingkungan mereka.

Pengembangan kemampuan kognitif anak merupakan kemampuan yang sangat diperlukan dimiliki oleh seorang guru. Kemampuan kognitif membutuhkan rangsangan untuk perkembangannya. Anak memiliki kemampuan kognitif yang berbeda-beda. Perbedaan kemampuan kognitif ini harus difahami oleh seorang guru untuk mengetahui bagaimana mempersiapkan kegiatan yang akan merangsang pekerkembangan kongitif tersebut.
Indera yang baik akan membantu anak untuk mengembangkan kemampuan yang dimiliki oleh mereka. Guru harus memiliki pengetahun yang baik tentang kemampuan indera anak. Anak belajar dari indera yang mereka miliki. Dengan mengoptimalkan kemampuan indera yang dimiliki anak, guru bisa membantu anak untuk mengoptimalkan kemampuan belajar agar anak lebih bisa tanggap terutama dengan lingkungan mereka.

Anak memiliki bakat olahraga dan kemampuan seni yang beragam. Setiap anak memiliki perbedaannya. Guru harus bisa memberikan fasilitas yang memadai untuk mengembangakan kemampuan olahraga dan seni. Selain memberikan fasilitas guru juga harus mampu untuk menguasai kemampuan olahraga dan seni tersebut agar guru mudah untuk merancang pembelajaran yang berhubungan dengan kegiatan olahraga dan seni. Penguasaan media juga harus dimiliki oleh guru. Penguasaan media yang baik akan membantu guru untuk menjelaskan maksud pembelajaran kepada anak didiknya. Semakin media yang digunakan akan menarik anak untuk mengikuti kegiatan dan pembelajaran yang dilaksanakan.

3. Memahami kemajuan anak dalam setiap bidang pengembangan di TK/PAUD nilai 49.07 kriteria rendah

Memahami kemajuan anak dalam setiap bidang pengembangan dapat dikeahui salah satu dengan asessmen yang dilakukan kepada anak. Dari informasi asessmen tersebut dapat diketahui bagaimana perkembangan anak selama proses pembelajaran yang dilaksanakan. Wina Sanjaya (2008:296) pembelajaran pada dasar adalah proses penambahan informasi dan kemampuan baru. Dari penjelasan tersebut dapat 
diketahui proses pembelajaran merupakan perubahan informasi dan kemampuan baru. Keberhasilan pembelajaran tersebut dapat dilihat dari perubahan informasi dan kemampuan yang dimiliki oleh seseorang. Artinya kalau tidak ada perubahan pada informasi dan kemampuan yang dimiliki berarti proses pembelajaran yang dilalui tidak memberikan arti, teteapi sebaliknya apabila terjadi perubahan pada informasi dan meiningkatnya kemampuan baru yang dimilikinya berarti terjadinya pembelajaran yang berarti pada diri seseorang.

$$
\text { Masitoh dkk (2005:7) }
$$

perkembangan dan pertumbuhan merupakan suato proses dalam kehidupan manusia yang berlangsung secara terus-menerus sejak masa konsepsi sampai akhir hayat. Perkembangan anak Taman kanakkanak yang terentang antara usia empat sampai dengan enam tahun merupakan bagian dari perkembangan manusia secara keseluruhan. Perkembangan pada usia ini mencakup perkembangan fisik dan motorik, perkembangan kognitif, perkembangan sosial emosional, dan perkembangan bahasa.

Kemampuan melakukan penilaian akan memberikan kemudahan bagi guru untuk merancang pembelajaran. Menurut Mulyasa dalam Ifat Fatimah Zahro (2015) penilaian merupakan suatu proses pengumpulan, pelaporan, dan penggunaan informasi tentang hasil belajar anak dengan menerapkan prinsip-prinsip penilaian berkelanjutan bukti-bukti auntentik, akurat dan konsisten. Dengan melakukan pengumpulan data guru jadi bisa mengetahui kondisi anak didik. Gambaran kondisi anak didik akan memberikan kemudahan bagi guru untuk menentukan tindakan yang akan dilakukan dalam proses pembelajaran. Proses selanjutnya adalah melaporkan informasi yang didapatkan. Informasi ini sangat berguna terutama bagi guru sendiri dan orang tua. Informasi yang akurat dari guru akan memudahkan orang tua memahami anak mereka. Dengan adanya pemahaman yang sama akan terjalin kerjasama yang baik guru dan orang tua untuk mempersiapkan pendidikan untuk anak. Proses penilaian ini harus dilakukan dengan konsisten dan berkelanjutan. Proses berkelanjutan akan dapat memberikan gambaran perkembangan anak yang sebenarnya sehingga bakat dan minat anak dapat diakomodir dan dikembangkan dengan baik. Hal yang sama juga dikemukakan oleh Uyu wahyudin dalam Ifat Fatimah Zahro (2015) menjelaskan penilaian penting bagi guru untuk memberikan umpan balik apa yang diperlukan untuk menyempurnakan proses pembelajaran

Slameto dalam upuh Fathurrohman dan M. Sobry Sutikno (2007: 10) menyebutkan ciri-ciri perubahan dalam belajar yakni (1) perubahan yang terjadi berlangsung secara sadar, sekurang-kurangnnya sadar bahwa pengetahuannya bertambah, sikapnya berubah, kecakapannya bekembang, (2) perubahan dalam belajar bersifat kontinieu dan fungsional, belajar bukan fungsi statis karena terus berkembang secara gradual dan setiap hasil belajar memiliki makna dan guna yang praktis, (3) perubahan belajar bersifat positif dan aktif, belajar senantiasa menuju perubahan yang lebih baik, (4) perubahan dalam belajar bukan bersifat sementara, bukan hasil belajar jika perubahan itu sesaat, (5) perubahan dalam belajar bertujuan dan terarah, sebelum belajar seseorang hendaknya menyadari apa yang akan berubah pada dirinya melalui belajar, (6) perubahan mencakup seluruh aspek tingkah laku, 
bukan bagian-bagian tertentu secara parsial.

Untuk guru dengan dilakukan proses asessmen tersebut akan memudahkan guru dalam proses mengajar. Dalam konsep mengajar ada beberapa hal yang harus diperhatikan seperti yang dikemukakan oleh Syamsu Yusuf LN (2007:168): (1) Mengajar adalah menanamkan pengetahuan pada anak. Dengan demikian tujuan mengajar adalah penguasaan pengetahuan oleh anak. Disini anak besifat pasif, dan guru memegang peran yang utama (bersifat Teacher Centered), (2) Mengajar adalah menyampaikan kebudayaan kepada anak, tujuan mengajar menurut pengerian ini adalah pengenalan kebudayaan (nasional dan dunia) oleh anak. Peran peserta didik pasif, sementara guru bersifat aktif, (3) Mengajar adalah suatu aktivitas mengkoordinasi atau mengatur lingkungan sebaik-baiknya dan menghubungkan dengan anak sehingga terjadi proses belajar. Menurut pengertian ini yang aktif adalah anak (pupil-centered), sementara guru hanya menjadi fasilitator, pembimbing, atau "manejer learning".

\section{SIMPULAN}

Hasil penelitian terdapat 12 (dua belas) indikator yang termasuk dalam kategori tinggi yaitu:

1 Menguasai konsep dasar matematika sebagai sarana pengembangan untuk setiap bidang pengembangan anak

2 Menguasai konsep dasar sains sebagai sarana pengembangan untuk setiap bidang pengembangan anak
3 Menguasai konsep dasar seni sebagai sarana pengembangan untuk setiap bidang pengembangan anak

4 Menguasai konsep dasar pendidikan jasmani sebagai sarana pengembangan untuk setiap bidang pengembangan anak

5 Menguasai alat permainan untuk pengembangan aspek fisik anak TK/PAUD

6 Menguasai alat permainan untuk pengembangan aspek sosial budaya anak TK/PAUD

7 Menguasai alat permainan untuk pengembangan aspek bahasa anak TK/PAUD

8 Menguasai berbagai permainan anak

9 Memahami tujuan setiap kegiatan pengembangan

10 Melakukan refleksi terhadap kinerja sendiri secara terus menerus

11 Mengikuti kemajuan zaman dengan belajar dari berbagai sumber

12 Memanfaatkan teknologi informasi dan komunikasi untuk pengembangan diri

Yang termasuk dalam kategori rendah ada 3 (tiga) indikator, yaitu:

1 Menguasai konsep dasar kesehatan dan gizi sebagai sarana pengembangan untuk setiap bidang pengembangan anak

2 Memahami kemampuan anak TK/PAUD dalam setiap bidang pengembangan

3 Memahami kemajuan anak dalam setiap bidang pengembangan di TK/PAUD 


\section{DAFTAR PUSTAKA}

Febrialismanto. 2015. Analisis kompetensi profesional guru di Taman Kanak-kanak Kecamatan Kampar Provinsi Riau. Jurnal educhild Vol 4 (1) februari 2015. 8-16

Febrialismanto. 2010. Kontribusi Kompetensi Profesional dan Kompetensi Pedagogik terhadap kinerja mengajar guru: Studi korelasional terhadap guru taman kanakkanak kecamatan Kampar provinsi Riau. Tesis ini tidak diterbitkan. Bandung: SPS UPI Bandung

Ifat, F., Z. 2015. Penilaian Dalam Pembelajaran Anak Usia Dini. Jurnal Tunas Siliwangi. Vol 1 (1) oktober 2015. 92-111

Kunandar. 2007. Guru Profesional, Implementasi Kurikulum Tingkat Satuan Pendidikan (KTSP) dan Persiapan Menghadapi Sertifikasi Guru. Jakarta: Raja Grafindo Persada.

Masitoh dkk. 2005. Pendekatan Belajar Aktif di Taman Kanak-Kanak. Departemen Pendidikan Nasional Direktorat Jenderal Pendidikan Tinggi Direktorat Pembinaan Pendidikan Tenaga Kependidikan dan Ketenagaan Perguruan Tinggi. Jakarta: Diknas.

Pupuh, F., \& Sutikno, M., S. 2007. Strategi Belajar Mengajar Melalui Penanaman Konsep Umum \& Konsep Islami. Bandung: Refika Adima.

Rita, K. 2015. Pendidikan Gizi Untuk Anak Usia Dini. Jurnal educhild Vol 4 (2) September 2015: 109-114

Ria, N., \& Febrialismanto. 2015. Pengaruh Penggunaan Media Mind Mapping Terhadap Kemampuan Membaca Anak Usia 5-6 Tahun di TK FKIP UNRI. Jurnal educhild Vol 4 (2) September 2015: 103-108
Sanjaya, W. 2009. Strategi Pembelajaran Berorientasi Standar Proses Pendidikan. Jakarta: Kencana Prenada Media Group.

Sukamti, E., R. 1994. Pengaruh gizi terhadap pertumbuhan dan perkembangan anak. Jurnal Cakrawala Pendidikan Nomor 3 Tahun XIII November 1994: 139-153

Syamsu, Y., L., N. 2007. Buku Materi Pokok Pedagogik Pendidikan Dasar. Bandung: Sekolah Pasca Sarjana Universitas Pendidikan Indonesia.

Yuhetty, Harina, dkk. 2009. Kajian Kompetensi Guru Dalam Meningkatkan Mutu Pendidikan. Jakarta: Bidang Mutu Pendidikan Mendiknas. 